\title{
PENGARUH TERAPI MUSIK KLASIK TERHADAP PERKEMBANGAN KOGNITIF ANAK RETARDASI MENTAL DI SEKOLAH LUAR BIASA (SLB) NEGERI PEMBINA MATARAM
}

\author{
"Ni Putu Sumartini, H. Moh. Arip, Muhamad Tarmizi \\ Keperawatan, Poltekkes Kemenkes Mataram, *email: arjunprabhata@gmail.com
}

\begin{tabular}{l} 
INFO ARTIKEL \\
\hline Riwayat Artikel: \\
Diterima: 15-10-2019 \\
Disetujui: 28-07-2020 \\
\hline
\end{tabular}

\section{Kata Kunci:}

Retardasi mental Perkembangan kognitif Musik klasik

\section{A. LATAR BELAKANG}

Retardasi mental adalah keadaan taraf perkembangan kecerdasan di bawah normal sejak lahir atau masa anak-anak, biasanya terdapat perkembangan mental yang kurang secara keseluruhan (Dalami, 2009). Retardasi mental atau tunagrahita merupakan istilah yang digunakan untuk menyebut anak atau orang yang memiliki kemampuan intelektual dibawah rata-rata, terjadi gangguan dalam fungsi intelektual subnormal melalui dilakukan tes psikologis dengan tes taraf kecerdasan atau Intelligence Quotient (IQ) dimana anak akan mempunyai IQ dibawah 70 (Smart, 2010).

Fungsi-fungsi perkembangan anak retardasi mental ada yang tertinggal jauh oleh anak normal, ada pula yang sama atau hampir menyamai anak normal seperti perkembangan fisik yang meliputi perkembangan jasmani dan motorik. Sementara perkembangan kognitifnya jauh berbeda dengan anak normal. Anak retardasi mental kesulitan dalam menangkap informasi yang kompleks, sulit memahami pelajaran yang diberikan, kesulitan mengerjakan tugas - tugasnya, kesulitan dalam hal mengingat segera (immediate memory) dan kesulitan dalam memecahkan masalah 
(Somantri, 2012).

Hasil analisis dari Global Burden of Disease 2004 didapatkan bahwa $15,3 \%$ populasi dunia (sekitar 978 juta orang dari 6,4 milyar estimasi jumlah penduduk dunia tahun 2004) mengalami disabilitas sedang atau parah, dan 2,9\% atau sekitar 185 juta mengalami disabilitas parah. Pusat Data dan Informasi (Pusdatin), Kesejahteraan Sosial Departemen Sosial RI Tahun 2007, mencatat jumlah penyandang cacat mental adalah 2.364.0oo jiwa termasuk penyandang cacat mental.

Data dari Dinas Sosial Kependudukan dan Catatan Sipil Provinsi Nusa Tenggara Barat Tahun 2015, jumlah penyandang cacat (disabilitas) adalah 16.976 jiwa. Jumlah penyandang cacat retardasi mental atau tunagrahita di wilayah Nusa Tenggara Barat menempati urutan kedua tertinggi setelah penyandang kecacatan tubuh, yaitu sebanyak 3.398 jiwa. Jumlah penyandang disabilitas yang bersekolah tingkat SD di SLB Negeri Pembina Mataram tahun 2017 sejumlah 83 siswa dengan siswa retardasi mental 65 siswa.

Hasil studi pendahuluan yang telah dilakukan pada Oktober 2017 di SLB Negeri Pembina Mataram didapatkan jumlah penyandang retardasi mental di tingkat SD dari kelas I sampai kelas VI adalah 65 orang. Dari 10 siswa yang diwawancarai, semua siswa mengatakan senang mendengarkan musik, tetapi tidak mengetahui tentang musik klasik. Peneliti juga mewawancarai orang tua siswa yang memiliki retardasi mental yang bersekolah di tingkat SD mengatakan anak mereka kesulitan untuk memahami pelajaran, disamping juga seorang guru di SLB Negeri Pembina Mataram mengatakan selama ini belum pernah memberikan terapi musik klasik kepada para siswa retardasi mental.

Suharnan (2005), dalam bukunya Psikologis Kognitif mengungkapkan bahwa transfer informasi dari ingatan indera (ingat sensori) menuju pada ingatan jangka pendek yang selanjutnya akan ditransfer ke ingatan jangka panjang sangat dipengaruhi oleh konsentrasi. Salah satu bentuk terapi yang digunakan saat ini adalah terapi musik, karena selain musik dapat menciptakan suasana yang menyenangkan, musik juga diketahui dapat mempengaruhi proses kognitif.

Irawaty (2013) menyatakan terdapat beberapa jenis musik yaitu musik jazz, musik tradisional, musik klasik dan musik dari alam, tetapi musik klasik seringkali menjadi acuan untuk terapi musik, karena musik klasik memiliki kecenderungan untuk menenangkan tubuh. Pengaruh musik klasik dalam kehidupan untuk menciptakan daya konsentrasi, memori, dan persepsi ruang. Dapat pula digunakan untuk mengiringi belajar maupun bekerja (Hastomi, 2012). Terapi musik bisa dilakukan dua kali sehari dengan durasi 30 menit. Meskipun tampaknya tidak mendengarkan, musik khusus untuk terapi anak dengan retardasi mental akan bekerja mempengaruhi gelombang otak (Azmira, 2015).

Ahli saraf dari Harvard University, Mark Tramo, M.
D., dalam buku Terapi Musik (2015) menyatakan getaran musik yang masuk melalui telinga dapat mempengaruhi kejiwaan. Ini terjadi karena di dalam otak manusia terdapat jutaan sel saraf (neuron) dari sirkuit secara unik menjadi aktif ketika kita mendengarkan musik. Neuron-neuron ini menyebar ke berbagai daerah di otak, termasuk pusat auditori di belahan kiri dan belahan kanan. Mulai dari sinilah kaitan antara musik dan kecerdasan terjadi.

Musik klasik juga dapat menurunkan stres, penelitian yang dilakukan oleh Regina dan Prabowo tahun 2007 mengenai tritmen musik untuk menurunkan stres dengan metode mendengarkan musik klasik pada mahasiswa, hasilnya menunjukkan adanya perbedaan yang signifikan terhadap stres sebelum dan sesudah perlakuan, dan hasilnya menunjukkan bahwa terapi musik klasik dapat mengurangi tingkat stres pada mahasiswa (Prabowo \& Regina, 2007).

Musik klasik juga dapat menurunkan tekanan darah. Turana (2011), menyatakan bahwa rangsangan musik dapat mengaktivasi jalur-jalur spesifik di dalam beberapa area otak, seperti sistem limbik yang berhubungan dengan perilaku emosional. Dengan mendengarkan musik klasik, sistem limbik ini teraktivasi dan individu tersebut pun menjadi rileks. Saat keadaan rileks inilah tekanan darah menurun.

Penelitian ini bertujuan untuk mengetahui apakah terapi musik klasik memiliki pengaruh terhadap perkembangan kognitif anak dengan retardasi mental di SLB Negeri Pembina Kota Mataram Provinsi Nusa Tenggara Barat. Penelitian ini juga akan memperkuat hasil penelitian sebelumnya oleh Sholikah (2015) tentang pengaruh terapi musik klasik.

\section{B. METODE PENELITIAN}

Penelitian ini menggunakan desain pre experimental dengan rancangan one group pre test and post test design. Populasi dalam penelitian ini adalah semua anak retardasi mental tingkat SD di SLB Negeri Pembina Mataram sejumlah 56 orang. Sampel dalam penelitian ini adalah anak retardasi mental tingkat SD di SLB Negeri Pembina Mataram yang sesuai kriteria inklusi. Besar sampel sebanyak 36 orang. Kriteria inklusi pengambilan sampel adalah anak retardasi mental tingkat SD kelas $3,4,5$ dan 6; tidak mengalami gangguan pendengaran dan bersedia menjadi responden dari awal sampai akhir penelitian. Pengumpulan data perkembangan kognitif dilakukan dengan kuesioner pengukuran perkembangan kognitif (Sutjihati, 1996). Perkembangan kognitif dikelompokkan menjadi baik, cukup dan kurang. Data perkembangan kognitif yang terkumpul selanjutnya dianalisis menggunakan Wilcoxon Match Pairs Test dengan tingkat signifikansi $95 \%(\alpha=0,05)$. 


\section{HASIL DAN PEMBAHASAN}

\section{Karakteristik Responden}

TABEL 1.

Distribusi Responden Berdasarkan Umur, Jenis Kelamin dan Klasifikasi Retardasi Mental di SLB Negeri Pembina Mataram, April 2018

\begin{tabular}{|c|c|c|c|c|}
\hline No & \multicolumn{2}{|c|}{$\begin{array}{c}\text { Karakteristik } \\
\text { Responden }\end{array}$} & $\mathbf{N}$ & $\%$ \\
\hline \multirow[t]{3}{*}{1} & \multirow{2}{*}{ Umur } & 6-12 tahun & 19 & 52,78 \\
\hline & & 13-18 tahun & 17 & 47,22 \\
\hline & \multicolumn{2}{|c|}{ Jumlah } & 36 & 100 \\
\hline \multirow[t]{3}{*}{2} & \multirow{2}{*}{ Jenis Kelamin } & Laki-laki & 21 & 58,33 \\
\hline & & Perempuan & 15 & 41,67 \\
\hline & \multicolumn{2}{|c|}{ Jumlah } & 36 & 100 \\
\hline \multirow[t]{3}{*}{3} & \multirow{3}{*}{$\begin{array}{c}\text { Klasifikasi } \\
\text { Retardasi } \\
\text { Mental }\end{array}$} & Moron & 14 & 38,89 \\
\hline & & Imbesil & 22 & 61,11 \\
\hline & & Jumlah & 36 & 100 \\
\hline
\end{tabular}

Berdasarkan tabel di atas didapat bahwa responden terbanyak menurut kelompok umur berada pada usia 612 tahun (usia sekolah) sebanyak 19 orang atau dengan persentase 52,78 \%. Responden terbanyak menurut jenis kelamin yaitu laki-laki sebanyak 21 orang atau dengan persentase 58,33 \%. Responden terbanyak menurut klasifikasi retardasi mental berdasarkan nilai IQ yaitu anak dengan klasifikasi retardasi mental imbesil sebanyak 22 anak atau dengan persentase $61,11 \%$.

\section{Perkembangan Kognitif Responden Sebelum dan Sesudah Diberikan Intervensi Terapi Musik Klasik}

TABEL 2.

Distribusi Perkembangan Kognitif Responden Sebelum dan Sesudah Diberikan Intervensi Terapi Musik Klasik di SLB Negeri Pembina Mataram, 1125 April 2018

\begin{tabular}{cccccc}
\hline \multirow{2}{*}{ No } & $\begin{array}{c}\text { Kategori } \\
\text { Perkembangan } \\
\text { Kognitif }\end{array}$ & $\mathbf{n}$ & $\mathbf{\%}$ & $\mathbf{n}$ & $\mathbf{\%}$ \\
\cline { 3 - 6 } & Baik & 5 & 13,89 & 19 & 52,78 \\
\hline 1 & Cukup & 9 & 25,00 & 11 & 30,55 \\
\hline 2 & Kurang & 22 & 61,11 & 6 & 16,67 \\
\hline 3 & Jumlah & 36 & 100 & 36 & 100 \\
\hline &
\end{tabular}

Berdasarkan tabel di atas menunjukkan bahwa sebagian besar responden sebelum diberikan terapi musik klasik berada pada kategori perkembagan kognitif kurang yang terdiri dari 22 orang atau dengan persentase $61,11 \%$. Kemudian sesudah diberikan terapi musik klasik sebagian besar responden berada pada kategori perkembangan kognitif baik yang terdiri dari 19 orang atau dengan persentase $52,78 \%$.

Hasil uji statistik menggunakan Wilcoxon Match Pairs Test diperoleh mean rank sebesar 17,50 dengan nilai $\mathrm{p}$ value $=0,000$ yang berarti $\mathrm{p}<\alpha=0,05$. Dengan demikian Ho ditolak dan Ha diterima. Dapat disimpulkan bahwa terapi musik klasik memiliki pengaruh pada perkembangan kognitif anak retardasi mental di SLB Negeri Pembina Mataram.

\section{a. Perkembangan Kognitif Sebelum Diberikan Terapi Musik Klasik}

Berdasarkan hasil penelitian yang dilakukan di SLB Negeri Pembina Mataram, dari 36 responden menunjukkan bahwa sebagian besar responden memiliki perkembangan kognitif kurang yaitu sebanyak 22 orang $(61,11 \%)$ dan hanya sebagian kecil responden yaitu 5 orang $(13,89 \%)$ yang memiliki perkembangan kognitif baik. Retardasi mental dibagi menjadi tiga yaitu retardasi mental ringan (moron), retardasi mental sedang (imbesil) dan retardasi mental berat (idiot). Retardasi mental ringan memiliki nilai IQ 50-69, sementara retardasi mental sedang dan retardasi mental berat memiliki IQ dibawah 50. Anak dengan fungsi intelek dibawah normal tidak dapat mengikuti pendidikan biasa, daya tangkap dan daya ingatnya lemah. Hal ini diikuti oleh keterlambatan fungsi perkembangan motorik dan kognitif anak (Somantri, 2012). Kondisi ini dapat disebabkan gangguan perkembangan fungsi otak yang mencakup bidang sosial dan afek, komunikasi verbal (bahasa) dan non-verbal, imajinasi, fleksibiliti, minat, kognisi dan tumpuan. Sehingga perlu proses waktu yang lama untuk membentuk perkembangan kognitif tanpa adanya terapi yangefektif (Somantri, 2012). Jika anak sering dikonfrontasikan dengan situasi yang multidimensional seperti terapi musik maka anak akan memusatkan perhatiannya hanya pada dimensi tersebut (Yanuarita, 2012).

Perkembangan kognitif anak retardasi mental jauh ketinggalan dengan anak normal. Untuk mencapai perkembangan kognitif yang sesuai, anak retardasi mental memerlukan pengulangan tentang bahan yang diajarkan (Somantri, 2012). Faktor yang mempengaruhi tahap perkembangan menurut Piaget dalam (Desmita, 2009) mengidentifikasi empat faktor yang mempengaruhi transisi tahap perkembangan anak, yang pertama yaitu kematangan, pengalaman fisik/lingkungan, transmisi sosial dan equilibrium. Kematangan memiliki peranan penting dalam perkembangan intelektual, akan tetapi faktor ini saja tidak mampu menjelaskan segala sesuatu tentang perkembangan intelektual. Penelitian-penelitian yang dilakukan dibeberapa negara membuktikan adanya perbedaan rata-rata umur pada tahap perkembangan yang sama.

Hasil penelitian ini sejalan dengan hasil penelitian yang dilakukan Hady (2014) tentang pengaruh terapi musik klasik terhadap perkembangan kognitif pada anak autis di SLB Autis Kota Surakarta, didapatkan ratarata perkembangan kognitif anak autis dengan kategori kurang sebelum diberikan terapi musik klasik.

Hasil penelitian lain yang dilakukan Rizka Moniqe (2016) tentang pengaruh terapi murottal terhadap perkembangan kognitif anak retardasi mental di SLB Negeri Banjar Mendalan menunjukkan rata-rata perkembangan kognitif pada anak retardasi mental 
sebelum diberikan terapi murottal yaitu dengan kategori kurang. Dengan tingkat kemampuan terendah 5 dan tingkat kemampuan tertinggi 8 sebelum dilakukan terapi murottal.

Dalam penelitian yang dilakukan di SLB Negeri Pembina Mataram, sebelum diberikan terapi musik kemampuan kognitif responden rata-rata berada dalam kategori kurang. Perkembangan kognitif anak retardasi mental yang masih kurang disebabkan kondisi anak retardasi mental yang memiliki daya tangkap dan daya ingat yang lemah hal ini dapat dilihat hasil observasi berdasarkan skala perkembangan kognitif didapatkan 22 orang $(61,11 \%)$ masih belum bisa memahami instruksi serta menganalisis pertanyaan yang diberikan. Hal ini mungkin disebabkan karena sebelumnya responden tidak pernah dilatih atau diberikan terapi musik klasik.

\section{b. Perkembangan Kognitif Sesudah Diberikan Terapi Musik Klasik}

Berdasarkan hasil penelitian yang dilakukan di SLB Negeri Pembina Mataram, dari 36 responden menunjukkan bahwa sebagian besar responden memiliki perkembangan kognitif baik yaitu sebanyak 19 orang $(52,78 \%)$ dan hanya sebagian kecil responden yaitu 6 orang $(16,67 \%)$ yang memiliki perkembangan kognitif kurang.

Setelah dilakukan terapi musik klasik didapatkan perbedaan antara perkembangan kognitif anak retardasi mental antara sebelum dan sesudah diberikan terapi musik klasik. Musik klasik ditemukan untuk meningkatkan kecerdasan seperti kemampuan penalaran. Musik klasik merangsang pemikiran, memperbaiki kosentrasi dan ingatan, serta dapat meningkatkan kognitif (Campbell, 2002).

Salah satu manfaat terapi musik yaitu meningkatkan kecerdasan, dibuktikan oleh penelitian yang dilakukan oleh Frances Rauscher et al dari Universitas California telah membuktikan tentang hal ini. Penelitian ini juga membuktikan masa dalam kandungan dan bayi adalah waktu yang tepat menstimulasi otak anak agar menjadi cerdas. Usia ideal untuk memulai pelajaran musik adalah antar 3-6 tahun, sebab di usia tersebut perkembangan indra pendengaran tengah berlangsung. Dengan demikian, musik bisa merangsang perkembangan otak (Yanuarita, 2012).

Dalam otak manusia terdapat reseptor sinyal (sinyal penerima) yang bisa mengenali musik.Musik merupakan salah satu stimulasi untuk mempercepat dan mempersubur perkembangan otak, bila anak terbiasa mendengar musik yang indah, banyak sekali manfaat yang bisa dirasakan anak. Tidak saja meningkatkan kognisi anak secara optimal juga dapat membangun kecerdasan emosional, perkembangan motorik dan kemampuan berbahasa (Hastomi, 2012).

Musik klasik yang digunakan dalam penelitian ini adalah musik klasik jenis mozart. Istilah Mozart effect (efek mozart) diciptakan pada 1995 oleh para ilmuwan di Universitas California yang menemukan bahwa ternyata siswa mendapat nilai yang lebih baik pada tes IQ spasial setelah mendengarkan musik mozart (Indocropcirles, 2012). Musik mozart tidak hanya berperan dalam kecerdasan tetapi juga dalam peningkatan konsentrasi. Penelitian ilmiah telah membuktikan bahwa dengan mendengarkan mozart secara signifikan dapat membantu untuk memfokuskan pikiran dan meningkatkan kinerja otak (Tempo, 2012).

Setiap musik yang kita dengarkan walaupun hal tersebut tidak sengaja didengarkan, akan berpengaruh pada otak. Terdapat tiga sistem syaraf otak yang dapat dipengaruhi oleh musik yaitu sistem otak yang memproses perasaan, sistem otak kognitif, sistem otak yang mengontrol kerja otot. Pada sistem otak kognitif, aktivasi sistem ini bisa terjadi walaupun seseorang tidak mendengarkan atau memperhatikan musik yang sedang diputar. Musik akan merangsang sistem ini secara otomatis walau tanpa disimak atau memperhatikan. Jika sistem ini dirangsang maka seseorang dapat meningkatkan memori, daya ingat, konsentrasi, kemampuan belajar, kemampuan matematika, analisis, logika, intelegensi, kemampuan memilah, disamping itu juga adanya perasaan bahagia dan timbulnya keseimbangan sosial (Yanuarita, 2012).

Hasil penelitian ini sejalan dengan hasil penelitian yang dilakukan Silvia (2016) tentang pengaruh terapi musik klasik terhadap perkembangan kognitif anak autis di Sekolah Khusus Autis Garegeh Bukittingi didapatkan hasil tes kemampuan kognitif pada 5 responden setelah dilakukan intervensi terapi musik klasik diperoleh mean 22.2 dengan standar deviasi 1.78. Hal ini memperlihatkan bahwa dengan terapi musik klasik yang dilakukan di Sekolah Khusus Autis Garegeh Bukittingi dapat memberikan perkembangan kognitif pada anak autis.

Hasil penelitian lain yang dilakukan Wulandari (2012) tentang pengaruh terapi musik klasik terhadap kemampuan kognitif pada anak penderita autisme di sekolah kebutuhan khusus Denpasar, didapatkan hasil pada tes kemampuan kognitif 15 responden mengalami peningkatan (100\%) setelah diberikan terapi musik klasik di SLB Denpasar.

Hasil observasi setelah perlakuan pada hari ke dua pada masing-masing anak, didapati sebagian responden berada pada kategori perkembangan kognitif baik yang terdiri dari 19 orang (52.78\%), sudah mampu melakukan instruksi baik pada kemampuan mengingat dan pemahaman. Peningkatan kemampuan mengingat dan memahami mungkin disebabkan karena adanya efek dari pemberian terapi musik klasik kepada responden sesuai dengan teori dan prosedur yang ada.

\section{c. Pengaruh Terapi Musik Klasik Terhadap Perkembangan Kognitif Anak Retardasi Mental Di SLB Negeri Pembina Mataram}

Berdasarkan uji statistik menunjukkan bahwa pemberian terapi musik klasik menyebabkan peningkatan perkembangan kognitif anak yang mengalami retardasi mental. Hal ini dapat dilihat dari tabel hasil penelitian yang telah disajikan 
sebelumnya. Pada tabel tersebut tersaji secara jelas dari 36 responden sebelum diberikan terapi musik klasik bahwa hampir setengah anak retardasi mental mempunyai perkembangan kognitif kurang yaitu sebanyak 22 anak $(61,11 \%)$ dan sebagian kecil anak retardasi mental perkembangan kognitif baik sebanyak 5 anak (13,89\%). Setelah diberikan terapi musik klasik perkembangan kognitif responden mengalami peningkatan dengan perkembangan kognitif terbanyak yaitu perkembangan kognitif dengan kategori baik sebanyak 19 responden (52,78\%) sedangkan responden dengan perkembangan kognitif kurang menjadi sebanyak (16,67\%). Berdasarkan hasil pengujian dengan uji wilcoxon didapatkan $\mathrm{p}<\mathrm{O}, \mathrm{O} 5$ maka H1 diterima, artinya terapi music klasik efektif terhadap perkembangan kognitif anak mengalami retardasi mental di SLB Negeri Pembina Mataram.

Musik klasik yang digunakan dalam penelitian ini adalah musik klasik jenis Mozart. Istilah Mozart effect (efek Mozart) diciptakan pada 1995 oleh para ilmuwan di Universitas California yang menemukan bahwa ternyata siswa mendapat nilai yang lebih baik pada tes IQ spasial setelah mendengarkan musik Mozart. Para ilmuwan juga mencoba musik trance, musik minimalis, audio-books, dan instruksi relaksasi, namun tidak ada yang berpengaruh seperti musik Mozart (Indocropcirles, 2012).

Musik klasik adalah nada atau suara yang disusun demikian rupa sehingga mengandung irama, lagu dan keharmonisan yang merupakan suatu karya sastra zaman kuno yang bernilai tinggi. Musik klasik merupakan perpaduan instrumen yang menggunakan violin, biola, piano, dan cello sebagai musiknya. Musik klasik memiliki perangkat musik yang baraneka ragam, sehingga didalamnya terangkum warna warni suara yang rentang variasinya sangat luas. Dengan kata lain variasi bunyi pada musik klasik jauh lebih kaya dari pada variasi bunyi musik yang lain. Kerenanya musik klasik menyediakan variasi stimulasi yang sedemikian luasnya bagi pendengar (Lindquist, 2014).

Musik-musik klasik mempunyai keunggulan akan kemurnian dan keserderhanaan bunyi-bunyi yang dimunculkan, irama, melodi, dan frekuensi-frekuensi tinggi pada musik klasik merangsang dan memberi daya pada daerah-daerah kreatif dan motifasi pada otak. Musik klasik memberi rasa nyaman tidak saja ditelinga tetapi juga bagi jiwa yang mendengarnya (Halim Samuel, 2007).

Dari hasil penelitian pada pre dan post pengukuran kemampuan kognitif, dapat dilihat seluruh responden mampu menjawab kuesioner pada nomor 1 (satu) dengan bunyi soal pengenalan secara intensif terhadap obyek atau benda-benda yang ada di lingkungan sekitar responden. Sementara itu, hanya 3 responden $(8,33 \%)$ pada pretest dan 7 responden $(19,44 \%)$ pada posttest yang dapat menjawab pertanyaan pada kuesioner nomor
5 (lima) dengan bunyi soal deskriminasi huruf yang hampir sama bunyinya. Hal demikian dapat terjadi karena kuesioner pada soal nomor 1 (satu) merupakan hal yang sehari-hari dijumpai oleh responden di lingkungan sehingga anak dengan mudah menjawab tugas perkembangan tersebut. Sementara itu pada soal nomor 5 (lima) anak harus mengingat bentuk huruf dan membedakan penyebutan masing-masing huruf. Sebagaimana yang diketahui anak retardasi mental tidak memiliki daya ingat yang kuat, oleh karena itu hal tersebut merupakan sesuatu yang sulit bagi anak retardasi mental.

Dalam penelitian yang dilakukan, sebelum diperdengarkan musik klasik, responden terlebih dahulu dilakukan pengukuran kemampuan kognitif. Musik klasik diperdengarkan kepada responden sebanyak dua kali dengan durasi 30 menit dalam satu kali terapi. Setelah diberikan terapi musik klasik selama dua kali, kemudian dilakukan pengukuran kemampuan kognitif kembali sebagai perbandingan antara pengukuran sebelum dan sesudah diberikan terapi musik klasik. Terdapat perubahan yang signifikan pada responden sebelum dan sesudah diberikan terapi musik klasik. Hal ini terlihat pada kenaikan jumlah responden yang memiki perkembangan kognitif baik dari 5 orang responden $(13,89 \%)$ menjadi 19 orang responden (52,78\%). Hal tersebut menunjukkan bahwa terapi musik klasik yang diberikan kepada anak yang mengalami retardasi mental memberikan efek meningkatkan perkembangan kognitif.

Peneliti menganalisa terapi musik klasik memang dapat meningkatkan perkembangan kognitif dibuktikan meningkatnya kemampuan pengetahuan, pemahamam dan analisis responden. Terbukti pada responden yang menjalani terapi musik musik klasik dapat mengingat, memahami dan menganalisis setiap pertanyaan. Meskipun masih ada responden yang tetap dalam perkembangan kategori kurang tetapi hal tersebut tidak membuat bahwa terapi musik klasik tidak efektif terhadap perkembangan kognitif anak retardasi mental karena pada kenyataannya responden yang tetap dalam perkembangan kognitif kurang tidak mengalami peningkatan perkembangan kognitif dilihat dari kualitas tetapi terjadi peningkatan dalam segi kuantitas. Dengan demikian terapi musik klasik efektif meningkatkan perkembangan kognitif anak retardasi mental di SLB Negeri Pembina Mataram.

\section{SIMPULAN DAN SARAN}

\section{Simpulan}

a. Sebagian besar responden memiliki perkembangan kognitif kurang sebelum diberikan terapi musik klasik.

b. Sebagian besar responden memiliki perkembangan kognitif baik setelah diberikan terapi musik klasik.

c. Terapi musik klasik efektif terhadap peningkatan perkembangan kognitif anak 
retardasi mental di SLB Negeri Pembina Mataram.

\section{Saran}

a. Bagi Poltekkes Kemenkes Mataram

Hasil penelitian ini dapat dijadikan sebagai bahan pustaka dalam menambah pengetahuan khususnya tentang efektivitas terapi musik klasik terhadap perkembangan kongnitif anak retardasi mental dan sebagai sarana pembanding bagi dunia ilmu pengetahuan untuk penelitian selanjutnya terutama dalam bidang kesehatan.

b. Bagi SLB Negeri Pembina Mataram

Hasil penelitian ini dapat dijadikan bahan masukan agar dapat dijadikan menjadi bagian dari terapi yang diberikan di sekolah khususnya untuk kebutuhan belajar siswa retardasi mental sebagai terapi tambahan yang dapat dimasukkan ke dalam kegiatan ekstakurikuler minimal dua kali seminggu sebagai upaya meningkatkan kognitif siswa.

c. Bagi Orang Tua Siswa Retardasi Mental

Hasil penelitian ini disarankan dapat menjadi pertimbangan bagi orang tua siswa yang mengalami retardasi mental agar menjadikan terapi musik klasik sebagai salah satu terapi alternatif yang diberikan kepada anak ketika anak sedang belajar di rumah untuk meningkatkan perkembangan kognitif.

d. Bagi Penelitian Selanjutnya

Hasil penelitian ini direkomendasikan untuk penelitian lebih lanjut tentang efektivitas terapi musik klasik terhadap peningkatan perkembangan kognitif anak retardasi mental dengan jumlah responden yang lebih banyak dan desain metode penelitian yang lebih baik lagi. Selain itu, perlu melibatkan keluarga dalam melakukan terapi.

\section{UCAPAN TERIMA KASIH}

Peneliti mengucapkan terima kasih kepada Jurusan Keperawatan Poltekkes Kemenkes Mataram.

\section{DAFTAR RUJUKAN}

[1] Ary, D., Lucy C.J., dan Chris S. 2010. Introduction to Research in Education Eighth Edition. Canada: Nelson Education Wadsworth Cengage Learning.

[2] Azmira. 2015.A Gift Anak Hiperaktif. Yogyakarta: Rapha Publishing.

[3] Champbell. 2002. Terapi Musik Teori Dan Aplikasi. Yogyakarta: Galang Press.

[4] Cohen, L., Lawrence M., dan Keith M. 2007. Research Methods in Education, Sixth Edition. London: Routledge Falmer.

[5] Dalami, E, dkk. 2009. Asuhan Keperawatan Klien Dengan Gangguan Jiwa. Jakarta: Trans Info Media.

[6] Desmita, 2009. Psikologi Perkembangan Peserta Didik. Bandung: Remaja Rosdakarya

[7] Dharma, K. K. 2011. Metodologi Penelitian Keperawatan. Jakarta: Trans Info Media.
[8] Efendi, M. 2009. Pengantar Psikopedagogik Anak Berkelainan. Jakarta: PT Bumi Aksa.

[9] Hastomi. 2012. Terapi Musik. Jakarta: Javalitera.

[10] Hendra, A. 2010. Pengaruh Pemberian Musik Klasik Terhadap Prestasi Belajar Matematika Anak. Skripsi Fakultas Psikologi Universitas Katolik Soegijapianata, Semarang.

[11] Hidayat, A. A. 2008. Riset Keperawatan dan Tehnik Penulisan Ilmiah. Jakarta: Salemba Medika.

[12] Hidayat, A.A. 2009. Kebutuhan Dasar Manusia. Jakarta: Salemba Medika.

[13] Hidayat, A. A. 2009. Pengantar Ilmu Keperawatan Anak 1. Jakarta: Salemba Medika.

[14] Indocropcicles. 2017. Misteri Musik Mozart terhadap Kesehatan dan Kecerdasan. [internet]. Tersedia dalam www.indocropcircles.wordpress.com/2012/02/o3/ misteri-musik-mozart-terhadap-kesehatandankecerdasan. Diakses pada tanggal 30 Oktober 2017 pukul 19.52 WITA.

[15] Kathlyn. 2001. Quick Reference To Occuptional Therapy. Texas : Housten Center.

[16] Lindquist, R. 2014. Complementary/Alternative Therapies in Nursing. New York: Springer Publishing Company.

[17] Meggitt. 2013. Memahami Perkembangan Anak. Jakarta: Indeks.

[18] Notoatmodjo, 2012. Metodologi Penelitian Kesehatan Edisi Revisi. Jakarta: Rineka Cipta.

[19] Nursalam, 2015. Metodologi Penelitian Keperawatan Pendekatan Praktis. Jakarta: Salemba Medika.

[20]Pandji, D. 2013. Sudahkah Kita Ramah Anak Special Needs. Jakarta: PT Medika Komputindo.

[21] Potter \& Perry, 2005. Buku Ajar Fundamental Keperawatan Edisi 4 Volume 1. Jakarta: EGC

[22] Primadita, A. 2011. Efektifitas Intervensi Terapi Musik Klasik Terhadap Stres Dalam Menyusun Skripsi. Skripsi Fakultas Psikologi Universitas Diponegoro, Semarang.

[23] Republika. 2010. Benarkah Musik Mozart Mampu Tingkatkan Kecerdasan ? . [Internet]. Tersedia dalam http://www.republika.co.id/berita/gayahidup/parenting/ 10/o5/13/115495/benarkah-music-Mozart-mampu tingkatkan-kecerdasan. Diakses pada tanggal 30 Oktober 2017 pukul 19.41 WITA.

[24] Ristia Pratiwi. 2017. Pengaruh Terapi Musik Klasik Mozart Terhadap Perilaku Hiperaktif Anak Autis.Skripsi Fakultas Ilmu Keperawatan Universitas Ngudi Waluyo, Semarang.

[25] Riwidikdo, H. 2012. Statistik Kesehatan. Yogyakarta: Mitra Cendikia Press.

[26] Romadoni, Siti. 2013. Pengaruh Terapi Musik Klasik Terhadap Penurunan Tekanan Darah Pada Pasien Hipertensi. Skripsi Fakultas Ilmu Keperawatan Stikes Muhammadiyah, Palembang.

[27] Samuel, Halim. 2007. Efek Mozart Dan Terapi Musik Dalam Dunia Kesehatan. Jakarta: PT Media Komputindo.

[28] Sholikah, S. Pengaruh Terapi Musik Klasik Terhadap Perkembangan Kognitif Anak Yang Mengalami Retardasi Mental Di SDLB Negeri Banjar Mendalan, Lamongan. Surya Volume 07 Nomor 01. Hal. 39-46 April 2015.

[29] SLBN Pembina Mataram. 2017. Data Register Dan Profil Sekolah. Mataram: SLBN Pembina Mataram.

[30]Smart, A. 2010. Anak Cacat Bukan Kiamat Metode Pembelajaran Dan Terapi Untuk Anak Berkebutuhan Khusus. Yogyakarta: Kata Hati.

[31] Soetjiningsih. 2015. Tumbuh Kembang Anak. Jakarta: EGC.

[32] Somantri, S. 2012. Psikologi Anak Luar Biasa. Bandung: PT Refika Aditama.

[33] Sugiyono. 2015. Statistik Non Parametrik. Jakarta: Alfabeta. 
[34] Suharnan. 2005. Psikologi Kognitif. Surabaya: Srikandi.

[35] Tempo. 2012. Musik mozart paling efektif tingkatkan konsentrasi. [Internet]. Tersedia dalam 092840/musikmozartpalingefekliftingkatkankonsentrasi. Diakses pada tanggal 30 Oktober 2017 pukul 19.37 WITA.

[36] Yanuarita, F. A. 2012. Memaksimalkan Otak Melalui Senam Otak (Brain Gym). Yogyakarta: Teranova Books.

\section{PROFIL PENULIS UTAMA}

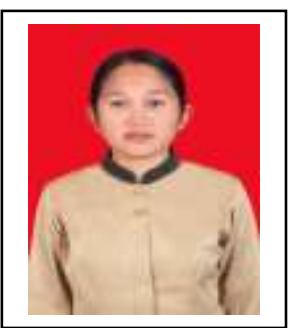

$\mathrm{Ni}$ Putu Sumartini, dosen Jurusan Keperawatan Poltekkes Kemenkes Mataram. 